\title{
Project-Based Electronic Module Development As A Supporting Learning Media For Basic Programming Learning
}

\author{
Reny Kartika Ningtyas ${ }^{1}$, Handaru Jati ${ }^{2}$ \\ ${ }^{1}$ Technology and Vocational Education, Universitas Negeri Yogyakarta, Indonesia \\ Email: reny.kartika2016@ student.uny.ac.id \\ ${ }^{2}$ Computer and Information Science, Universitas Negeri Yogyakarta, Indonesia \\ Email: handaru@uny.ac.id
}

(Received: October-2018; Reviewed: October-2018; Accepted: November-2018; Published: December-2018) access under license CC BY-NC-4.0 (https://creativecommons.org/licenses/by-nc/4.0/ ).

\begin{abstract}
This study aims to develop and determine the feasibility of electronic modules or e-modules based on the project based learning (PBL) method in Basic Programming Subjects at SMK Negeri 1 Japara Kuningan, West Java. This study uses research and development methods. The development procedure adopts the Lee and Owens model with four stages, namely: analysis stage, design stage, developing and implementation stage, and evaluation stage. At the evaluation stage several stages are carried out, namely: Alpha test to determine the validity of product feasibility conducted by material experts and design expert. Then proceed with a beta test carried out to one group. The research subjects were students of class X majoring in Multimedia. The instrument used in this research is a validation sheet and questionnaire sheet. The results of the qualitative data will be converted into quantitative data using a scale from 1 to 4 , then the rating scale is converted to determine the feasibility of the project based learning e-module PBL. The results show that the appraisal of the feasibility of the product gets a decent feasibility from the design expert and is very feasible from the material expert. Evaluation on beta tests found that $8.6 \%$ considered quite feasible, $71.4 \%$ said it was feasible, and $20 \%$ said it was very feasible.
\end{abstract}

Keywords: Electronic module; e-module; project based learning

\section{INTRODUCTION}

The working world of the 21 st century is increasingly fierce and demands knowledge, creativity, innovation, and can develop themself in adapting to changes in the work environment and technological developments. Miyamoto (2017) in the ILO 2017 Report revealed that technology and work always have mutually symbiotic relationships. It is said that technological changes are in line with the time to create new jobs and industries. In other words, technology is the catalyst of growth.
Vocational education in Indonesia which is intended to print competent and ready to compete for human resources is still not optimal. The data from the Central Bureau of Statistics (BPS) shows that the highest number of unemployed comes from Vocational Schools (SMK) with a total of $8.92 \%$. Yahya (2018: 10) The cause of the high contribution of vocational education to the number of unemployed is due to the low special skills and soft skills possessed. Paor (2018:9) teachers also need to learn new approaches for their own teaching practices, and ICT skills for assessment. Teachers need to possess teaching and learning skills with profesional attributes in 
industry realtion and practical skills Ismail et al., (2016:31)

Vocational Schools are focused on providing skilled workforce in various sectors such as industry, agriculture and technology to enhance economic development. Sudira (2012) stated that the preparation of several competencies must be done because vocational education is an education that prepares students especially to work in certain fields. Therefore Vocational Schools must be able to cultivate a learning process that helps students to learn actively.

One effort to develop active learning that can be an alternative is to use electronic media or known as e-learning. Karwati (2014: 53) suggests that e-learning has a strong positive influence on the quality of learning. In the discussion of the development of active learning approaches many provide extraordinary evidence between the effectiveness of active learning and passive delivery. Aricò \& Lancaster (2018:12) utilizing learning technology has the advantage of producing large data, the data can be analyzed to uncover learning patterns to help students who have difficulties and support the teacher in the continuous process of learning revision. Such evidence can guide to create course design toward strategies that engage both conceptual knowledge and procedural knowledge Noteborn, Dailey-hebert, Bohle, \& Gijselaers (2014:213).

In this study will try to develop an e-learning model in the form of an online electronic module that has the basis of a project based learning method (PBL). Syamsuddin (2005) modules based on elearning aim to change learning behavior with the interaction between users without face to face, while Patton (2012) project based learning (PBL) refers to activities to design, plan and implement projects that produce product output that can be published. Amamou \& Cheniti-belcadhi (2018:184) project-based learning environment can taking advantage of teacher to ensures a high level of autonomy and enchances learning flexibility. It is expected that the development of electronic project based learning modules can improve the active learning process of students so that students have sufficient competence when working later. In addition, this development wanted to find out how much the feasibility of an e-learning model using the PBL method obtained from students toward active learning.

\section{METHOD}

The study procedure adopted a four-stage ADDIE model by Lee and Owens (2004: 3) The phases in developing the e-module project based learning is presented in Figure 1.

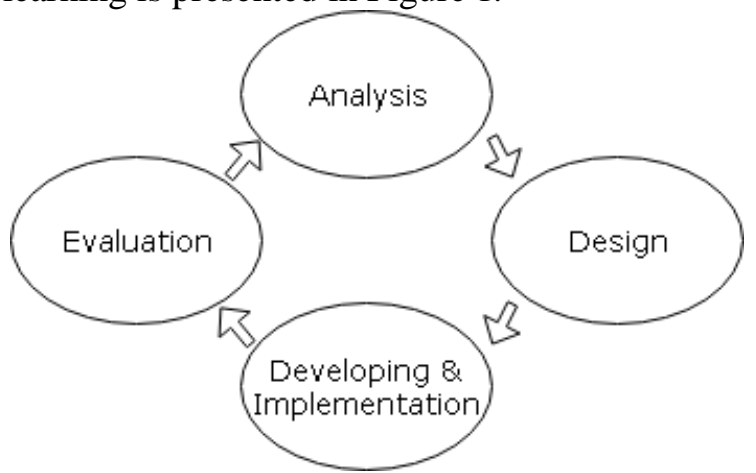

Figure 1. Development Model Lee and Owens

(Source: Lee and Owens 2004)

This study developed was electronic module with based method using project based learning. The following specifications shown in Table 1.

Table 1. Specifications and Requirements

\begin{tabular}{ll}
\hline Component & \multicolumn{1}{c}{ Information } \\
\hline Navigation & $\begin{array}{l}\text { Button search, homepage, } \\
\text { courses, account user }\end{array}$ \\
File Type & HTML and HTML5 (Google \\
& Chrome, Mozila Firefox, \\
& Opera Mini) \\
Video & .mpeg, .mp4 \\
Audio & Standart audio (mp3, wav, \\
& wave) \\
Picture & .jpeg, .png \\
Animation & .swf, .gif \\
Document & .doc, .pdf \\
Others & Link website, link video \\
&
\end{tabular}

Alfa and beta testing were conducted to ensure that the e-module PBL is able to answer the formulated problems. The alpha test aimed to test the feasibility of e-module PBL was done by the experts of design and materials. The input provided by experts is used for product revision and improvement before being implementated in the field test. Alpha test is used by experts to measure product feasibility. Meanwhile the beta test is used by dtudents to measure the effectiveness of product. This study used two kinds of questionnaire to collect the data: (1) a questionnaire in the alpha test for the experts; (2) a questionnaire in the beta test for students. 
Table 2. The Content Outline of the Alpha Test Instrument by expert design

\begin{tabular}{cll}
\hline Aspect & Indicator & \multicolumn{1}{c}{$\begin{array}{c}\text { Point of } \\
\text { Statement }\end{array}$} \\
\hline \multirow{4}{*}{ interface } & Compatibility & $1,2,3,4,5,6,7,8,9$ \\
& explication & $10,11,12,123,14,15$ \\
& attractiveness & $16,17,18,19,20,21,22$ \\
& proportions & $23,24,25,26$ \\
& simplicity & $27,28,29,30,31$ \\
& explication & $32,33,34,35$ \\
utilization & availability & $36,37,38,39,40$ \\
& sophisticated & $41,42,43$ \\
& magnetism & $44,45,46$ \\
\hline
\end{tabular}

Table 3. The Content Outline of the Alpha Test Instrument by experts material

\begin{tabular}{cll}
\hline Aspect & \multicolumn{1}{c}{ Indicator } & \multicolumn{1}{c}{$\begin{array}{c}\text { Point of } \\
\text { Statement }\end{array}$} \\
\hline \multirow{3}{*}{ Content } & suitability & $1,2,3,4,5,6,7,8,9$ \\
material & accuracy & $10,11,12,13,14,15$ \\
& validity & $16,17,18,19,20,21$ \\
& up-to-date & $22,23,24,25,26,27$ \\
& techniques & $28,29,30,31,32,33$ \\
& supporting & $34,35,36,37,38,39$ \\
Presentatio & presentation & $40,41,42,43,44,45$, \\
n & of learning & $46,47,48$ \\
& completeness & $49,50,51,52,53,54$, \\
& of presentation & $55,56,57,58,59,60$ \\
\hline
\end{tabular}

Table 4. The Content Outline for Beta Test Instrument by students

\begin{tabular}{cll}
\hline \multirow{2}{*}{ Aspect } & \multicolumn{1}{c}{ Indicator } & \multicolumn{1}{c}{$\begin{array}{c}\text { Point of } \\
\text { Statement }\end{array}$} \\
\hline & clarity & $1,2,3$ \\
& ease & 4,5 \\
Preliminary & accuracy & $6,7,8$ \\
& relevance & 9 \\
& completeness & 10,11 \\
Content/ & clarity & 12,13 \\
description & vastness \& & $14,15,16,17$ \\
of material & deepness & \\
& attractiveness & $18,19,20$ \\
\hline
\end{tabular}

The data that has been obtained will be analyzed using quantitative methods to describe the feasibility and effectiveness. The evaluation sheet will use four assessment categories that respondents can choose. The assessment is classified as very high, high, low, very low with the order 4,3,2 and 1 respectively. The score will be converted into four scales adopted from Wagiran (2013: 339) as follows:
Table 5. The Value Conversion in the Scale of five

\begin{tabular}{lc}
\hline \multicolumn{1}{c}{ Interval } & Category \\
\hline Above $(\mathrm{Mi}+1,5 \mathrm{SD}) \mathrm{sd}(\mathrm{Mi}+3 \mathrm{SD})$ & Very High \\
Above Mi sd Mi $+1,5 \mathrm{SD}$ & High \\
Above Mi $-1,5 \mathrm{SD}$ sd $\mathrm{Mi}$ & Moderate \\
Mi - 3 SD sd Mi $-1,5 \mathrm{SD}$ & Low \\
\hline
\end{tabular}

Where:

Mi $($ Ideal Average $)=\frac{1}{2}($ ideal maximum score + ideal minimum score)

$\mathrm{SD}($ ideal standart deviation $)=\frac{1}{\epsilon}($ ideal maximum scorel + ideal minimum score)

$\mathrm{X}=$ empirical score

Table 5 shows that ideal maximum score is 4 and the ideal minimum score is 1 . The interval of $\mathrm{M}$ and SD is as follows:

$$
\begin{aligned}
& \mathrm{M}=\frac{1}{2}(4+1)=2.5 \\
& \mathrm{SD}=\frac{1}{\epsilon}(4-1)=0.5
\end{aligned}
$$

Table 6. Qualitative to Quantitative Data Conversion

\begin{tabular}{llll}
\hline Scale & Criteria & Calculation & Result \\
\hline 4 & Very & $2.5+1.5(0.5)=2.5+$ & $3.25>4$ \\
& Feasibility & $3(0.5)$ & \\
3 & Feasibility & $2.5=2.5+1.5(0.5)$ & $2.5<3.25$ \\
2 & Quite & $2.5-1.5(0.5)=2.5$ & $1.75<2.5$ \\
& Feasibility & & \\
1 & Less & $2.5-3(0.5)=2.5-1.5$ & $1<1.75$ \\
& Feasibility & $(0.5)$ & \\
\hline
\end{tabular}

To get the average score of e-module PBL, the following formula is used:

$$
\begin{aligned}
& X_{i}=\frac{\Sigma x}{\Gamma \cdot \Omega \times \Gamma . n} \\
& \text { Where: } \\
& X_{\mathrm{i}}=\text { average score } \\
& \Sigma_{\mathrm{x}}=\text { total score } \\
& \Sigma_{\mathrm{a}}=\text { total of aspects } \\
& \sum_{\mathrm{n}}=\text { total of respondents }
\end{aligned}
$$

\section{RESULTS AND DISCUSSION}

\section{Result}

Electronic modules or e-modules are developed with methods based on project-based learning. E-module PBL will be designed as a learning medium to help the learning process of students and facilitate the demands of active learning. E-module PBL uses images, videos, animation, pdf, doc and notepad document files 
to help students in understanding Basic Programming learning. Systematics of the content of e-module content is made sequentially to prepare students to make a project making a group application as the end result of learning.

E-module PBL was developed using Moodle version 2.9. e-module PBL. E-module PBL can be accessed via the internet. E-module PBL can be opened on computer and mobile smartphone devices. e-module PBL development was validated in terms of feasibility carried out by four experts respectively, one design expert and three material experts. Input and revision from experts will be the addition and improvement of product quality using alpha test.

The results of alpha test data for design experts 1 gave a score of 126 divided into aspects of interface 66 and utilization score 60 with an average score of 3.00. it can be concluded that the assessment in terms of design is categorized as
"Feasibility". While the assessment of material experts 1 gave a total score of 226 which was divided into material content aspect scores 134 and aspects of presentation 89 with an average score of 3.8 and 3.7. then it can be concluded that the assessment of material experts 1 is categorized as "Very Feasibility". Expert material 2 gives a total score of 197 which is divided into material content aspects 115 and aspects of presentation 82 with an average score of 3.28. It can be concluded that the assessment of material expert 2 is categorized as "Very Feasibility". The assessment of material expert 3 gave a total score of 216 divided by content aspects of material 128 and aspects of presentation 88 with an average score of 3.65 and 3.52. then the assessment of material expert 3 can be concluded as the "Very Feasibility" category. Data details can be seen in Table 7 .

Table 7. Result of Expert Judgment

\begin{tabular}{|c|c|c|c|c|c|}
\hline Name Expertise & $\begin{array}{l}\text { Expert } 1 \\
\text { Design }\end{array}$ & & & & \\
\hline Design Aspects & Total Score & Maximum Score & Percentage & $\begin{array}{c}\text { Average } \\
\text { Score }\end{array}$ & Information \\
\hline & 126 & 168 & 100 & & \\
\hline Interface & 66 & 88 & 56.5 & 3.00 & Good \\
\hline Utilization & 60 & 80 & 43.5 & 3.00 & Good \\
\hline
\end{tabular}

\begin{tabular}{lccccc} 
Name Expertise & $\begin{array}{c}\text { Expert 1 } \\
\text { Material }\end{array}$ & & & & \\
Material Aspect & Total Score & Maximum Score & Percentage & $\begin{array}{c}\text { Average } \\
\text { Score }\end{array}$ & Information \\
\hline Content Material & 226 & 240 & 100 & & \\
Presentation & 134 & 140 & 58.3 & 3.8 & Very Good \\
& 89 & 100 & 41.7 & 3.7 & Very Good
\end{tabular}

\begin{tabular}{lccccc} 
Name Expertise & $\begin{array}{c}\text { Expert 2 } \\
\text { Material }\end{array}$ & & & & \\
Material Aspect & Total Score & Maximum Score & Percentage & $\begin{array}{c}\text { Average } \\
\text { Score }\end{array}$ & Information \\
\hline Content Material & 197 & 240 & 100 & & \\
Presentation & 115 & 140 & 58.3 & 3.28 & Very Good \\
& 82 & 100 & 41.7 & 3.28 & Very Good
\end{tabular}

\begin{tabular}{lccccc} 
Name Expertise & $\begin{array}{c}\text { Expert 3 } \\
\text { Material }\end{array}$ & & & & \\
Material Aspect & Total Score & Maximum Score & Percentage & $\begin{array}{c}\text { Average } \\
\text { Score }\end{array}$ & Information \\
\hline Content Material & 216 & 240 & 100 & & \\
Presentation & 128 & 140 & 58.3 & 3.65 & Very Good \\
& 88 & 100 & 41.7 & 3.52 & Very Good \\
\hline
\end{tabular}


After the product is declared feasible based on alpha tests by experts. Then the product will be implemented and field tested to one subject group. The field test group consisted of 35 students of class $\mathrm{X}$ majoring in multimedia in Basic Programming Subjects. Evaluation will be carried out with beta tests based on assessment aspects in Table 4. Questionnaire sheets are distributed to students after using the product for two semesters. Assessment of students will be a reference for the effectiveness of e-modules PBL.

Evaluation of the effectiveness of e-modules PBL is obtained: 20 questions with the composition of the preliminary aspects of $65 \%$ and the material / description of the contents of $35 \%$. The total score of assessment of all students is 2113 and the overall average score is 3.01. 3 students assessed the product "Quite Feasibility" with percentage $8.6 \%$, while as many as 25 people rated the product "Feasibility" with a percentage of $71.4 \%$, and the last 7 people rated "Very Feasibility" with a percentage of $20 \%$.

Figure 2. Alpha Test Result for aspects by experts

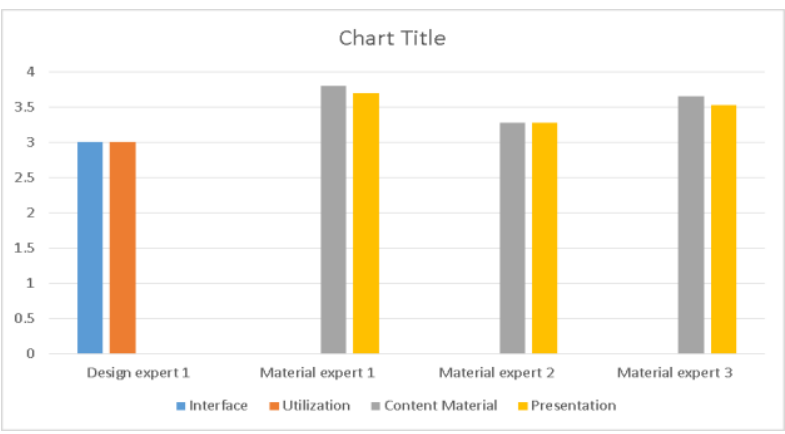

Figure 3. Alpha Test Feasibility Result

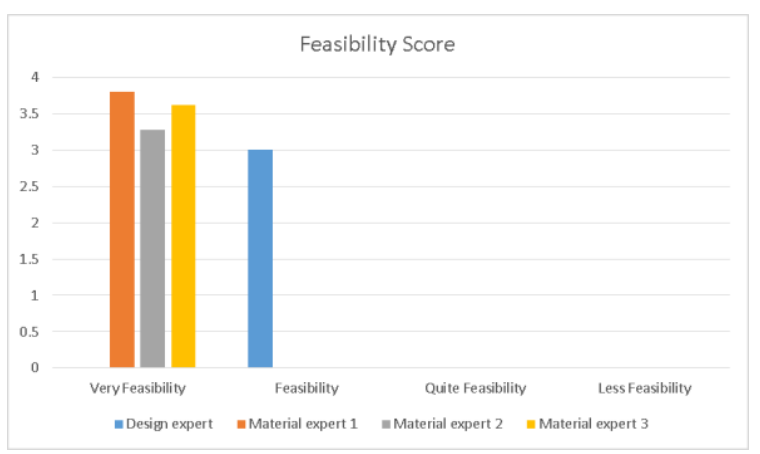

Figure 4. Result Evaluation Beta Test by Students

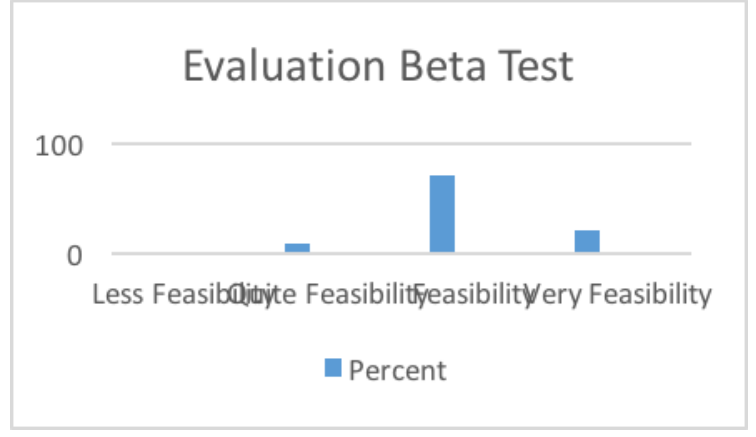

Figure 5. Average Beta Test Score

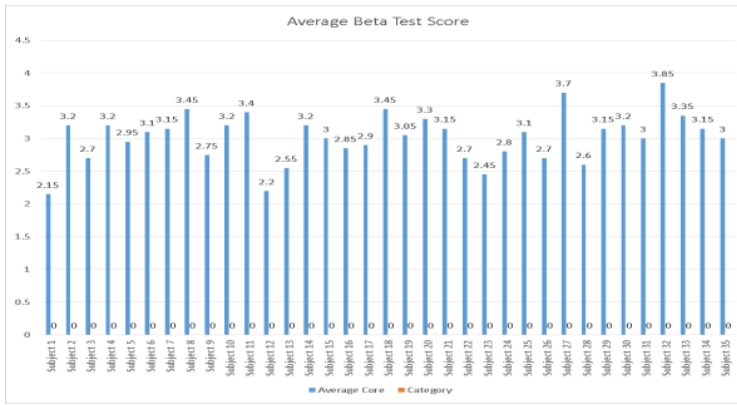

\section{Discussion}

It is said that the assessment of media expert gets the category "Feasibility" even though the score assessment is not large but the electronic design of the module is sufficient and can be used as a learning medium. While the assessment of material experts get the category "Very Feasibility" with an average value above than 3.00. With the basis of PBL learning combined with material choices that can help students to learn, find material, collect assignments, and various features to facilitate the learning process so they can study independently or share information. As Ismuwardani (2018:56) implementated PBL can increase self-reliance and creativity. It can be said that the high value obtained is sufficient from various aspects of learning given in the electronic module. We can be said the PBL aspects assisted by electronic media modules has more value than the learning that has been going on so far. especially in multimedia learning. In beta test for effectiveness of electronic modules PBL by students got "Feasibility" category that had the highest rating of $71.4 \%$ of 25 students. Almost of all students feel that the e-module developed is feasible and effective to be used for learning. So we can said the effectiveness of PBL e-modules can create a conducive and enjoyable learning atmosphere so students can be more active Nisa (2017:1053). 


\section{CONCLUSION AND SUGGESTIONS}

In the development of e-modules PBL uses Moodle version 2.9 as platform development. Emodule is designed as an alternative learning media to help the learning process and facilitate students' active learning. The materials are arranged sequentially to prepare an application making project that is carried out in groups as the end result of learning. E-module PBL is also packed with various media such as pictures, videos, animations, document pdf files, notepad for material, summaries, examples of coding, and glossaries. Assessment of the feasibility of the PBL e-module using alpha tests, the product gets an assessment from experts who provide the "Feasibility" category by the design expert and "Very Feasibility" by the material expert. In beta the test was carried out by students to assess the effectiveness of PBL e-modules as a learning tool. The assessment results show that $8.6 \%$ rate "Quite Feasibility", 71.4\% rate "Feasibility", and $20 \%$ judge "Very Feasibility".

Although project-based learning has great potential in terms of learning material. The design provided in the electronic module must be easier to understand and easy to use. The design should provide more beauty so that it helps simple functions that are implanted in electronic module.

\section{REFERENCES}

Amamou, S., \& Cheniti-belcadhi, L. (2018). ScienceDirect ScienceDirect Systems Learning Tutoring In Tutoring In ProjectBased Learning. Procedia Computer Science, $\quad 126, \quad 176-185$. https://doi.org/10.1016/j.procs.2018.07.221

Aricò, F. R., \& Lancaster, S. J. (2018). International Review of Economics Education Facilitating active learning and enhancing student self-assessment skills. International Review of Economics Education, 29 (June), 6-13. https://doi.org/10.1016/j.iree.2018.06.002

Badan Pusat Statistik. (2018). Keadaan Ketenagakerjaan Indonesia Februari 2018. No. 42/05/Th.XXI, 07 Mei 2018. Accessed on September $26^{\text {th }} 2018$.
International Labour Organization. (2017). Laporan Ketenagakerjaan Indonesia 2017: Memanfaatkan Teknologi untuk Pertumbuhan dan Penciptaan Lapangan Kerja. Jakarta: ILO.

Ismail, A., Hassan, R., Masek, A., Hamzah, N., Ismail, I. M., \& Subramaniam, T. S. (2016). Implementation of Vocational Training into TVET's Teacher Program for National Core Standard, 28-31.

Ismuwardani, Z., \& Nuryatin, A., \& Doyin, M. (2018). Implementation of Project Based Learning to Increased Creativity and Sel-Reliance of Students on Poetry Writing Skills. Journal of Primary Education. Accessed on December 23th 2018:

http://doi.org/10.15294/jpe.v8i1.25229

Karwati, E. (2014). The influence of e-learning based on information technology toward students quality of learning. Jurnal Penelitian Komunikasi Vol. 172014. Accessed on September $14^{\text {th }} 2018$ : https://www.researchgate.net/publication/2 96686483/download

Lee, W. and Owens, D. L. (2004). Multimedia Based Instructional Design: Computer Based Training Web Based Training Distance Broadcast Training, Performance Based Solutions $2^{\text {nd }} E d$. San Fransisco: Pfeiffer.

Nisa, I., I., R., Suswanto, H., \& Wirawan, I., M. (2017). Pengaruh Model Project Based Learning Terhadap Hasil Belajar Pada Mata Pelajaran Teknik Animasi Dua Dimensi Kelas XI Jurusan Multimedia. Jurnal Pendidikan: Teori, Penelitian, dan Pengembangan Vol. 2 No. 8 2017. p.10501053. Accessed on December 23th 2018: http://journal.um.ac.id/index.php/jptpp/

Noteborn, G., Dailey-hebert, A., Bohle, K., \& Gijselaers, W. (2014). Essential knowledge for academic performance: Educating in 
the virtual world to promote active learning. Teaching and Teacher Education, 37 , 217-234. https://doi.org/10.1016/j.tate.2013.10.008

Paor, C. De. (2018). Supporting change in VET: teachers 'professional development and ECVET learner mobility. Empirical Research in Vocational Education and Training, 1-13. https://doi.org/10.1186/s40461-017-0062-3

Patton, A. (2012). Work That Matters: The Teacher's Guide to Project-Based Learning. London: Paul Hamlyn Foundation.

Pressman, R. S. (2015). Rekayasa Perangkat Lunak:Pendekatan Praktisi Buku I. Yogyakarta: Andi.
Syamsuddin, A. (2005). Psikologi Kependidikan Perangkat Sistem Pengajaran Modul. Bandung: Rosdakarya.

Sudira, P. (2012). Filosofi dan Teori Pendidikan Vokasi dan Kejuruan. Yogyakarta: UNY Press.

Wagiran. (2014). Metodologi Penelitian Pendidikan: Teori dan Implementasi. Yogyakarta: Deepublish.

Yahya. M. (2018). Era Industri 4.0: Tantangan dan Peluang Perkembangan Pendidikan Kejuruan Indonesia. Makasar. http://eprints.unm.ac.id/6456 